\title{
GOVERNMENTAL INTERVENTIONS IN CONSTITUTIONAL LITIGATION: AN ANALYSIS OF SECTION 25 OF THE JUDICATURE ACT ${ }^{1}$
}

\author{
PATRICK BENDIN*
}

The Alberta Judicature Act requires that written notice be given to the Attorneys General for Canada and the Province whenever the constitutional validity of a Federal or Provincial enactment is challenged in a proceeding. The advent of Charter litigation has raised many questions and concerns about the scope and role of interveners. The author begins by outlining the legislative history and constitutional basis and validity of the notice requirement and then examines the scope of the notice requirement. It is submitted that the requirement of giving notice of a challenge to an enactment's constitutional validity should be seen in a wide sense so as to allow a government to be heard whenever their law making power is brought into issue. Proceedings and enactments to which the notice requirement applies are then outlined. The author deals with two objections to the notice requirement, the first being based on s. 52 of the Constitution Act, 1982 (the supremacy clause), the latter regarding the effect of $s .15$ of the Charter and the difference in provincial notice requirements and access to Charter protection. The author concludes with a short discussion on the governmental interest in interventions and submits that while the role played by the Attorneys General is important, there are circumstances where the rights of intervention should not be protected at the expense of private litigants.

\section{L'Alberta Judicature Act requiert que le} procureur général du Canada et de la province soit avisé par écrit chaque fois que la constitutionnalité d'une loi fédérale ou provinciale est contestée. L'avenement des litiges invoquant la Charte a soulevé de nombreuses questions et préoccupations quant au champ d'action et au rôle des intervenants. L'auteur commence par présenter l'historique législative, le fondement constitutionnel et la validité de l'obligation du préavis et examine ensuite la portée de l'obligation. Il propose que le préavis obligatoire soit perçu, au sens large, comme permettant au gouvernement d'être entendu chaque fois que son pouvoir d'édicter des lois est contesté. Les procédures et les textes auxquels s'applique l'obligation de préavis sont ensuite précisés. L'auteur examine deux objections à cette obligation la première s'appuie sur l'article 52 de la Loi constitutionnelle de 1982 (la clause de suprémacie). la seconde examine les effets de l'article 15 de la Charte et de la différence existant entre les obligations provinciales et l'accès à la protection de la Charte. L'auteur conclut par une brève discussion sur l'intérêt du gouvernement dans les interventions et propose que, s'il est vrai que le rôle du procureur général est important, il existe des circonstances out les droits d'intervention ne devraient pas être protégés aux dépens des plaideurs particuliers.

\section{TABLE OF CONTENTS}

I. INTRODUCTION $\ldots \ldots \ldots \ldots \ldots \ldots \ldots \ldots \ldots \ldots \ldots \ldots \ldots \ldots \ldots \ldots$

II. LEGISLATIVE HISTORY OF THE NOTICE REQUIREMENT IN ALBERTA $\ldots \ldots \ldots \ldots \ldots \ldots \ldots \ldots$

I. R.S.A., 1980 c.J-1.

- Counsel, Department of Justice. The author wishes to acknowledge the invaluable assistance rendered by William Henkel, Q.C., General Counsel, Department of the Attorney General for the Province of Alberta, at whose suggestion the task of writing an article on governmental interventions was undertaken and without whose counsel and encouragement the same would not have been completed. However, all views expressed in the article, logether with any errors and omissions, are solely attributable to the author and do not necessarily represent the position of the Department of Justice. 


\section{CONSTITUTIONAL BASIS OF SECTION 25}

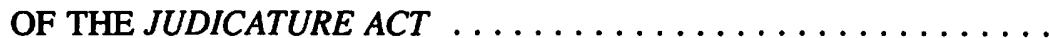

IV. SCOPE OF THE NOTICE REQUIREMENT $\ldots \ldots \ldots \ldots \ldots \ldots$

A. NOTICE OF QUESTIONS OF VALIDITY

AND APPLICABILITY $\ldots \ldots \ldots \ldots \ldots \ldots \ldots \ldots$

B. PROCEEDINGS TO WHICH THE NOTICE

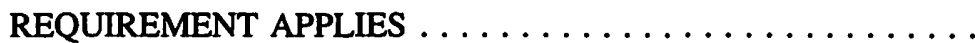

C. STATUTORY INSTRUMENTS ENCOMPASSED

BY REFERENCE TO AN ENACTMENT $\ldots \ldots \ldots \ldots \ldots \ldots$

V. OBJECTIONS TO THE NOTICE REQUIREMENT ...........

\section{INTRODUCTION}

In most provinces there is a statutory requirement to give written notice to the Attorneys General for Canada and the Province whenever the constitutional validity of an enactment of the Parliament of Canada or the Provincial legislature is challenged in a proceeding. ${ }^{2}$ Such legislation was presaged by the decision of the Privy Council in Russell v. The Queen ${ }^{3}$ in which the constitutional validity of the Canada Temperance Act, $1878^{4}$ was decided upon without argument from either the Attorney General for Canada or any of the provincial Attorneys General. The decision was subsequently the object of judicial comment in which it was suggested that a different result might have been reached had one or more of the provincial Attorneys General intervened. ${ }^{5}$ As Strayer noted, "[i]t is probably no coincidence that machinery was introduced in Canada soon after [Russell v. The Queen was decided] to ensure the appropriate Attorneys General would be notified of, and permitted to appear in, constitutional litigation".6

2 E.g. see: Constitutional Questions Act, R.S.B.C., 1979, c.63, s.8; as am. 1981, c.19, ss. 15 \& 16; 1982, c. 5, s. 1; Constitutional Questions Act, R.S.S., 1978, c.C-29; as am. 1983-84, c. 31, s. 8; Courts of Justice Act, S.O., 1984, c.11, s.122; 1989, c. 55, s. 21; Code of Civil Procedure, R.S.Q., 1977, c.C-25, Art.95; as am. 1985, c. 29, s. 6; Judicature Act, R.S.N.B., 1973, c.J-2, s.22; as am. 1980 , c.28, s.5; 1982, c.3, s.39(1). For a discussion of the Saskatchewan notice provision see: Richards, Robert G., "The Notice Provisions in the Constitutional Questions Act" (1989) 53 Sask. L. Rev. 153.

3. (1882), 7 App. Cas. 829.

4. S.C. 1878, c.16.

5. E.g. see: A.G. Ont. v. A.G. Can., [1896] A.C. 348 at 362; Re Board of Commerce, [1920] S.C.R. 456 at 507, Re National Products Marketing Act, [1936] S.C.R. 398 at 420.

6. Strayer, B.L., The Canadian Constitution and the Courts: The Function and Scope of Judicial Review, 2d ed. (Toronto: Butterworths, 1983) at 65, citing An Act to Facilitate the Intervention of the Crown in Civil Cases in Which the Constitutionality of a Federal or Provincial Act is in Question, S.Q., 1882, c.4, s.1 and An Act for the Better Administration of Justice in this Province, S.O., 1883, c.6, s.6. 
Prior to the coming in force of the Canadian Charter of Rights and Freedoms ${ }^{7}$ the purpose of the notice requirement was said to derive from the need to ensure that governments were represented in actions where the constitutional validity and applicability of their legislation was being challenged. Compliance with the notice requirement was regarded as a procedural safeguard which ensured constitutional issues were thoroughly canvassed through the participation of those having a continuing interest in the outcome of such questions. ${ }^{8}$ With the advent of Charter litigation and the expansion of the courts' jurisdiction to consider questions of public policy, concerns began to be expressed about the scope of the Attorneys General right of intervention relative to the right of intervention of individuals and public interest groups.

One manifestation of these concerns has been the espousal of a more liberal policy towards public interest interveners. ${ }^{9}$ The advocates of this view argue that the expansion in the power of judges to make law in the course of carrying out their adjudicative function together with the fact that judges are not elected and therefore not answerable to the public, requires that individual Canadians be given a greater opportunity to influence the way in which judges exercise their law-making powers. ${ }^{10}$ It is further argued that the role which can be played by public interest interveners in Charter litigation is qualitatively the same as the role played by Attorneys General and that, therefore, their rights of intervention should be placed on the same footing." In other words, whereas pre-Charter constitutional litigation involved questions of the relative scope of the jurisdiction of Parliament and the provincial legislatures, Charter litigation brings into issue the extent to which individual activity can be circumscribed or otherwise abridged or affected by governmental action. ${ }^{12}$ Hence, by affecting the relationship between individuals and the state, the Charter engages the interest and requires the participation of both.

However, equating the Attorneys General right of intervention with that of individuals and public interest groups necessarily implies a diminishment in the role of Attorneys General as interveners. That is, because it is not possible to determine a priori the individuals or public interest groups having sufficient standing to be heard in respect of a constitutional issue, the attainment of so-called equal footing would require the

7. Part 1, Constitution Act, 1882, Schedule B, Canada Act, 1982, (U.K.), c.11 (hereinafter referred to as the "Charter").

The Queen in Right of Ontario v. Board of Transport Commissioners (1967), 65 D.L.R. (2d) 425 at 434 (S.C.C.); Northern Telecom Ltd. v. Communication Workers of Canada et al (1980), 98 D.L.R. (3d) 1 at 19 (S.C.C.).

J. Welch, "No Room at the Top: Interest Group Intervenors and Charter Litigation in the Supreme Court of Canada" (1985) 43 University of Toronto Faculty of Law Review 204; K.P. Swan, "Intervention and Amicus Curiae Status in Charter Litigation" in R.J. Sharpe, ed. Charter Litigation (Toronto: Butterworths, 1987) at 27; P.L. Bryden, "Public Interest Intervention in the Courts" (1987) 66 Canadian Bar Review 490.

10. Welch, supra, note 9 at 228-31; Swan, supra, note 9 at 43, 44; Bryden, supra, note 9 at 505-06.

II. Welch, supra, note 9 at 226; Swan, supra, note 9 at 43; Bryden, supra, note 9 at 527-28.

12. Bryden, supra, note 9 at 511 . 
abrogation of the Attorneys General right of automatic intervention. Indeed, a procedural amendment of this type has already been advocated in the context of appeals to the Supreme Court of Canada where it has been suggested that, since non-governmental interveners are restricted to making written submissions, with oral arguments permitted only with leave of the Court, a similar rule should be applied to intervening Attorneys General. ${ }^{13}$

A reason often given for curtailing the Attorneys General right of intervention is that the present notice provisions tend to stack the deck in favour of the government. As Bryden explains: ${ }^{14}$

If the primary purpose of the Charter is to give Canadians a vehicle for asserting rights against government, it seems strange that governments that were not initially parties to the litigation should be provided with an automatic vehicle for conveying their message to the courts, while those interested in presenting a non-government perspective must depend on the willingness of the court to let their voices be heard.

The suggestion has even been made that, as between public interest interveners and the Attorneys General, the representations and contributions of the latter are the least significant and helpful to the court. ${ }^{15}$

While Attomeys General can no longer claim if ever they could, to be the sole guardians of the public interest, as chief law officers of the Crown they nonetheless retain a central role to play in shaping the jurisprudence which results from Charter litigation. ${ }^{16}$ Firstly, Attorneys General have a duty to safeguard the integrity of parliamentary government by defending the democratic values expressed in impugned legislation whenever the challenge to the validity of that legislation is based on values not found in the Charter. Secondly, Attorneys General are entitled to make representations whenever considerations of public policy, stemming from values found in the Charter, are in dispute. ${ }^{17}$ The purpose of this article is to examine the statutory provision by which the involvement of the Attorneys General for Canada and Alberta is facilitated in Charter and

13. Ibid. at 527-28 citing subsection 18(5) of the Rules of the Supreme Court of Canada as amended by S.O.R./87-292.

14. Ibid. at 511.

is. Swan, supra, note 9 at 28.

16. See: John L.L.J. Edwards, The Attorney General, Politics and the Public Interest (London: Sweet and Maxwell, 1984) at 134-45, 153-58; I.G. Scott, "The Role of the Attorney General and the Charter of Rights" in G.A. Beaudoin, Charter Cases 1986-1987; Proceedings of the October 1986 Colloquium of the Canadian Bar Association in Montreal (Cowansville (Quebec): Editions Y. Blais, 1987) at 41.

17. See the respective comments of Dickson, C.J.C. and Mclntyre, J. in Morgentaler, Smoling and Scott v. the Queen (1988), 44 D.L.R. (4th) 385 at 393, 394 and 465 (S.C.C.) regarding the role of the courts in interpreting the Charter and the extent to which they should resolve matters of public policy. 
other constitutional litigation and to consider the scope of this provision as well as its basis in policy and law.

\section{LEGISLATIVE HISTORY OF THE NOTICE REQUIREMENT IN ALBERTA}

From 1905, when Alberta became a province, to 1919, matters relating to the administration of justice were governed by the Judicature Ordinance of the North West Territories. ${ }^{18}$ Secton 59 required that parties give notice of their intention to challenge the constitutional validity of any ordinance of the Territories. In 1919 the Legislative Assembly of Alberta repealed the Judicature Ordinance of the North West Territories and replaced it with the Judicature Act, ${ }^{19}$ s. 34 of which provided as follows:

(1) When in any action or other proceeding the constitutional validity of any enactment of the Parliament of Canada or of the Legislature of the Province or of the North West Territories is brought into question the same shall not be held to be invalid unless notice has been given to the Attorney General for Canada or the Attomey General for Alberta, as the case may be.

(2) The Attomey General for Canada and the Attomey General for Alberta shall be entitled as of right to be heard, either in person or by counsel, notwithstanding that the Crown is not a party to the action or proceeding.

But for two minor amendments, the first having been made in $1922^{20}$ when the reference to the Legislature of the North West Territories was deleted and the second, in 1955 , $^{21}$ when the phrase "any action or other proceeding" in the first subsection was changed to read "an action or other proceeding" and the phrase "shall be entitled as of right" in the second subsection was amended to "is entitled as of right", the wording of the notice requirement remained unchanged until 1976. At that time the scope of the provision was expanded to include questions regarding the applicability of federal or provincial legislation to a particular situation. The added provision read as follows.:22

When in an action or other proceeding a question arises as to whether an enactment of the Parliament of Canada, or of the Legislature of Alberta is the appropriate legislation applying to or governing any matter in issue, no decision may be made thereon unless notice has been given to the Attomey General for Alberta and the Attomey General for Canada.

Cons. O.N.W.T. 1898, c.21. The provisions of the ordinance were continued in Alberta by section 16 of the Alberta Act, 4-5 Edward VII, c. 3 (Canada).

S.A., 1919, c.3.

R.S.A, 1922, c.72, s.34.

R.S.A, 1955, c.164, s.31.

The Judicature Act, s. 6 in The Attorney General Statutes Amendment Act, 1976 (No. 2), S.A., 1976, c.58. 
The notice requirement was further amended in $1981 .{ }^{23}$ The reference to an action was deleted and subsumed under the notion of a proceeding. A requirement that 14 days written notice be given to the Attorneys General for Canada and Alberta was added together with the stipulation that the contents of the written notice include a reference to the enactment or part thereof that is being challenged, as well as reasonable particulars of the proposed argument. The wording of the notice requirement was changed to make clear that, whichever government's legislation is being challenged, notice is to be given to both the federal and provincial Attorneys General. Provision was made for the Crown in right of either Canada or Alberta to be represented only by their respective Attorneys General or counsel designated by them. Finally, a limited right of appeal was given to the federal and provincial Attorneys General by deeming their status to be equivalent to that of a party in so far as questions regarding the constitutional validity of legislation are concerned. As a result of these changes the notice requirement now reads as follows: ${ }^{24}$

(1) If in a proceeding the constitutional validity of an enactment of the Parliament of Canada or of the Legislature of Alberta is brought into question, the enactment shall not be held to be invalid unless 14 days written notice has been given to the Attomey General for Canada and the Attomey General for Alberta.

(2) When in a proceeding a question arises as to whether an enactment of the Parliament of Canada or the Legislature of Alberta is the appropriate legislation applying to or goveming any matter or issue, no decision may be made on it unless 14 days written notice has been given to the Attorney General for Alberta and the Attomey General for Canada.

(2.1) The notice shall include what enactment or part of an enactment is in question and give reasonable particulars of the proposed argument.

(3) The Attomey General for Canada and the Attomey General for Alberta are entitled as of right to be heard, either in person or by counsel, notwithstanding that the Crown is not a party to the proceeding.

(4) No person other than the Attomey General for Alberta or counsel designated by him shall, on behalf of Her Majesty in right of Alberta or on behalf of an agent of Her Majesty in right of Alberta, appear and participate in any proceeding within or outside Alberta in respect of a question referred to in subsection (1) or (2).

(5) If the Attomey General or counsel designated by him appears in a proceeding within Alberta in respect of a question referred to in subsection (1) or (2), the Attomey General is deemed to be a party to the proceeding for the purpose of an appeal from an adjudication in respect of that question and has the same rights with respect to an appeal as any other party to the proceeding.

23. Judicature Amendment Act, S.A. 1981, c.51.

24. Judicature Act, supra, note 1 . 


\section{CONSTITUTIONAL BASIS OF SECTION 25 OF THE JUDICATURE ACT}

It is generally agreed that Section 25 of the Judicature Act is authorized by subsection 92(14) of the Constitution Act, $1867^{25}$ and therefore applicable in proceedings where the constitutional validity of provincial legislation is brought into issue. ${ }^{26}$ The question which arises, however, is whether the notice requirement is applicable on the same basis when the challenge is to the constitutional validity of federal legislation. According to Strayer: ${ }^{27}$

Serious doubts might be raised...about the validity of the provincial notice requirement where the provincial court is involved in a proceeding essentially within federal jurisdiction. Parliament can confer jurisdiction on provincial courts with respect to matters within federal legislative competence (Valin $\mathbf{v}$. Langlois (1879), 5 App. Cas. 115 (P.C.), Re Vancini (1904), 34 S.C.R. 621, 8 C.C.C. 228). In such proceedings can the provincial Legislature still limit the jurisdiction of its courts?

In Strayer's view, where a court is exercising a jurisdiction conferred on it expressly or impliedly by a federal statute, provincial limitations on its jurisdiction may be irrelevant. That is: ${ }^{28}$

If Parliament assigns to a provincial court the duty of applying certain federal laws must not the court apply the "whole law" taken in the context of constitutional limitations? If so, when provincial statutes of which the Constitutional Questions Act is typical, provide that: Where in a court in Saskatchewan the constitutional validity of an Act...of the Parliament of Canada or of the Legislature...is brought into question the Act...shall not be adjudged to be invalid until after notice has been given they may cut too wide a swath. To the extent that they purport to limit the jurisdiction of a court in a proceeding under federal statute they may be invalid.

The question of whether compliance with provincial notice requirements is necessary when challenging the constitutional validity of a federal enactment arose as an issue before Veit, J. of the Alberta Court of Queen's Bench in $R$. v. Stanger. ${ }^{29}$ The Crown argued that the failure of the Defence to give notice under section 25 of the Judicature Act precluded it from arguing an objection based on the Charter or that such objection if argued, could not result in the declaration by the court of the constitutional invalidity of section 8 of the Narcotic Control Act. In deciding that it was not necessary for the Defence to comply with the notice requirement and that the court was not precluded by such non-compliance from dealing with the constitutional issue raised, Veit, J. noted that, since the Narcotic Control Act constitutes legislation enacted under the general residual

25.

30-31 Vict., c.3 (U.K.).

Strayer, The Canadian Constitution and the Courts: The Function and Scope of Judicial Review, supra, note 6 at $72-73$.

27.

28.

29.

Ibid. at 73.

Ibid. at 73-74.

(1983), 70 C.C.C. (2d) 247. 
power, the imposition of a notice requirement is not supportable on the basis of the provincial power to enact laws in respect of the administration of criminal law..$^{30}$

On appeal to the Alberta Court of Appeal ${ }^{31}$ the question of whether section 25 of the Judicature Act was constitutionally valid had become moot since the requisite notice had been given. The court nonetheless agreed to consider the matter and concluded as follows: ${ }^{32}$

It seems to me that under the Charter, as in any other case, it is reasonable to require the court to have all parties who may be affected given notice. I do not regard the Judicature Act as doing anything other than requiring that notice be given to the state which has an interest in declarations about the validity of legislation. It is not legislation in relation to criminal procedure and in the cases before us there is no conflict with the procedural provisions of the Code.

The constitutional basis of provincial notice requirements was also considered by Killeen, J. of the Ontario District Court in $R$. v. Neely. ${ }^{33}$ The accused, who was prosecuted for having sexual intercourse with a 13 year old person who was not his wife, contrary to subsection 146(1) of the Criminal Code, applied to have the provision struck down as being violative of his equality rights under subsection 15(1) of the Charter. However, the application was brought without notice of the challenge having been given to the federal and provincial Attorneys General pursuant to section 122 of the Courts of Justice Act, S.O. 1984. ${ }^{34}$ In considering the effect of this omission Killeen, J. held that the requirement did not apply in respect of criminal proceedings. That is: ${ }^{35}$

I would have thought that the province's undoubted jurisdiction over the administration of justice in Ontario does not enable the province to erect conditions precedent to constitutional challenges of this kind in Criminal Code proceedings. As it seems to me, if anyone has the right to erect, as I put it, conditions precedent of the kind referred to in section 122 of the Courts of Justice Act 1984, it is the federal Parliament exercising its unquestioned power over criminal law and procedure.

He therefore went on to hear the challenge deciding, firstly, that subsection 146(1) of the Criminal Code breached the accused's equality rights under subsection 15(1) of the Charter and, secondly, that it did not constitute a reasonable limitation provided by law which is demonstrably justified in a free and democratic society. ${ }^{36}$ The Crown appealed the decision of Killeen, J. to the Ontario Court of Appeal ${ }^{37}$ though, as occurred in the Stanger case, ${ }^{38}$ the question of whether compliance with provincial notice requirements

Ibid. at 249.

(1984), 2 D.L.R. (4th) 121 at 131.

Ibid. at 146.

(1986), 22 C.C.C. (3d) 73.

Supra, note 2.

$R$. v. Neely, supra, note 33 at 75 .

Ibid. at 78, 79.

$R$. v. Lucas; $R$. v. Neely (1986), 27 C.C.C. (3d) 229.

Supra, note 31 . 
is necessary in such circumstances was rendered moot as a result of notification of the constitutional issue having been given to the Attorney General for Canada. The court nonetheless commented as follows with respect to the constitutional basis of the notice requirement: $^{39}$

...by virtue of s. 108(2) of the Courts of Justice Act, 1984 the notice of constitutional issue required by section 122 is to be served on the Attorney General of Canada and on the Attorney General of Ontario in proceedings under the Criminal Code. Obviously, the assumed constitutional basis for this provision is s. 92(14) of the Constitution Act, 1867 - the administration of justice in the province.

It is submitted that the decisions of the Alberta and Ontario Courts of Appeal follow from principles which govern the Canadian judicial system. Provincial courts of superior jurisdiction are inherently competent to deal with matters within federal jurisdiction so long as Parliament does not derogate from this power by establishing additional courts for the better administration of the laws of Canada. ${ }^{40}$ Furthermore, unless Parliament stipulates the procedure to be followed in respect of such matters proceedings before provincial superior courts would continue to be subject to procedural rules enacted for them under subsection 92(14) of the Constitution Act, 1867, including provisions such as section 25 of the Judicature Act. ${ }^{41}$ The same conclusion holds true in respect of provincial courts which derive their jurisdiction to regulate matters under section 91 of the Constitution Act, 1867 exclusively from statute. That is, even if Parliament does not adopt the procedure from time to time in force in respect of such courts, provincial rules of procedure would still apply if their adoption can be established by implication. ${ }^{42}$

An instructive description of the constitutional basis of provincial notice requirements is that given by Cavarzan. That is: ${ }^{43}$

(1) The administration of justice, insofar as it concerns the operation of provincial courts of inferior and superior jurisdiction, means the interpretation and application of provincial and federal law.

(2) Thus, though a notice requirement affects, for example, the procedure in criminal matters, it is not legislation in relation to criminal procedure. Rather, the object and purpose of the requirement is to ensure that the provincial courts can be effective arbiters of the Canadian federal system.

39. R. v. Lucas; $R$. v. Neely, supra, note 37 at 233.

40. Valin v. Langlois (1879), 3 S.C.R. 1 at 14-21; R. v Thomas Fuller Construction Co. (1958) Ltd., [1980] 1 S.C.R. 695 at 713.

41. Valin v. Langlois, supra, note 40 at 15.

42. Re B.C. Tree Fruit Marketing Board and R.H. MacDonald and Sons Ltd. et al (1983), 149 D.L.R. (3d) 500 at 508 (B.C.S.C.).

43. J. Cavarzan, "Judicature Act, R.S.O. 1980, c.223, s.35 - Notice of Constitutional Issue" (1984) 62 Can. Bar Rev. 75 at 79-80. 
Cavarzan goes on to note that there is a double aspect to the power to enact notice requirements in that Parliament is also empowered to make provision for the giving of notice whenever the challenge concerns the constitutional validity of federal legislation. ${ }^{44}$ As such, any notice requirement it might enact would, pursuant to the doctrine of paramountcy, prevail over the provincial requirement to the extent of any inconsistency.

\section{SCOPE OF THE NOTICE REQUIREMENT}

\section{A. NOTICE OF QUESTIONS OF VALIDITY AND APPLICABILITY}

Unlike subsection 25(1) of the Judicature Act the notice requirement in the Rules of the Supreme Court of Canadas draws a distinction between challenges to the constitutional validity of legislation and challenges that urge its inoperability. The following question therefore arises in relation to the provincial notice requirement: Does a challenge to the constitutional validity of an enactment only bring into issue the relative authority of Parliament and the legislature to pass laws or does it also include questions of Charter compliance?

In Re Gandam and Minister of Employment and Immigration ${ }^{46}$ an application was brought before Estey, J. of the Saskatchewan Court of Queen's Bench for a writ of certiorari to quash a deportation order. One of the grounds relied upon by the Applicant was that the procedure and conduct of the Immigration Appeal Board contravened section 7 of the Charter. Estey, J. dismissed the application on the grounds that the Charter had not enlarged the court's jurisdiction to deal with statutes of Parliament and that its jurisdiction to deal with such enactments, except as to their constitutionality, was limited by section 18 of the Federal Court Act. ${ }^{47}$ In that regard, Estey, J. stated as follows: ${ }^{48}$

\footnotetext{
A section of a statute may be absolutely within the power of the Parliament of Canada, but infringes upon the Charter. However, such a situation does not bring into being a constitutional question dealing with the validity of the statute.... The question which would arise is merely as to the existence of an inconsistency between the statute and the Charter and not as to the fact as to whether such section or sections of the Act be ultra vires or intra vires. The Charter in such a situation provides in very plain language that a person who deems that his rights or freedoms have been infringed upon or denied "may apply to a court of competent jurisdiction to obtain such remedy as the court considers appropriate and just in the circumstances."
}

\footnotetext{
44. Ibid.

45. SOR/83-74, s.32 as amended by SOR/84-821, s.1.

46. (1983), 140 D.L.R. (3d) 363.

47. R.S.C. 1970, c.10 (2nd Supp.).

48. Re Gandam, supra, note 46 at 368.
} 
In R. v. Oakes ${ }^{49}$ an accused charged with unlawful possession of a narcotic for the purpose of trafficking, contrary to subsection 4(2) of the Narcotic Control Act, ${ }^{50}$ brought a motion challenging the constitutional validity of section 8 of the Act on the basis that it infringed the presumption of innocence in paragraph 11(d) of the Charter by requiring him to prove that he is not guilty of trafficking once the basic fact of possession is proven. At the trial level Walter, J. held that it was unnecessary for the accused to give notice, pursuant to section 35 of the Judicature Act, ${ }^{51}$ of his intention to bring the motion. In so holding, Walter, J. stated as follows: ${ }^{52}$

In my view the constitutional validity referred to in section 35 of the Judicature Act refers to the legislative competence surrounding any enactment of the Parliament of Canada or the Provincial Legislature. By that I mean determination of whether or not the impugned enactment is ultra vires or intra vires the enacting legislature. Where, however, in a case such as the present the validity of the legislation is not being questioned in respect to the division of legislative powers set forth in the British North America Act 1867 but rather whether the enactment has been rendered inoperative or invalid by the Charter; I hold that it is not necessary to complete service of the notice contemplated by the Judicature Act.

The tenability of distinguishing between a challenge based upon the distribution of powers prescribed by the Constitution Act, 1867 and a challenge based on alleged violations of the Charter surfaced as an issue before the Trial Division of the Federal Court in Re Groupe des Eleveurs de Volailles De L'Est De L'Ontario et al v. Canadian Chicken Marketing Agency. ${ }^{53}$ The Applicant, who had been denied an interprovincial quota by the Canadian Chicken Marketing Agency, brought a motion for an order declaring, inter alia, that the provisions of the Chicken Marketing Quota Regulations ${ }^{54}$ under which the denial was made were inconsistent with sections 6(2)(b) and 7 of the Charter. The Respondent objected to the Court's jurisdiction to grant the requested relief and as well, sought a stay of proceedings pending the determination of a parallel action commenced by the Applicant in the Supreme Court of Ontario. ${ }^{55}$ The presiding trial judge, Strayer, J. dismissed the application for a stay of proceedings holding that it was unclear that the Supreme Court of Ontario had the power to issue any necessary declarations regarding the validity of actions taken under the impugned regulations. ${ }^{56}$

49. (1986), 26 D.L.R. (4th) 200 (S.C.C.) aff'g; (1983), 145 D.L.R. (3d) 123 (Ont. C.A.) aff'g; (1983) 38 O.R. (2d) 598.

so. R.S.C., 1970, c.N-1.

S1. R.S.O., 1980, c.223.

52. R. v. Oakes (1983), 38 O.R. (2d) 598. at 600-601. While the scope of the notice requirement was not broached on appeal by either the Ontario Court of Appeal or the Supreme Court of Canada it is nonetheless significant that both courts stated the issue for determination to be the constitutional validity of section 8 of the Narcotic Control Act.

53. (1985), 14 D.L.R. (4th) 151.

54. SOR/79-559.

55. Re Group des Eleveurs de Volailles De L'Est De L'Ontario et al v. Canadian Chicken Marketing Agency, supra, note 53 at $155-157,163$.

56. Ibid. at 165 . 
While recognizing that federal and provincial superior courts have concurrent jurisdiction to issue declarations to the effect that federal statutes or regulations are in conflict with the distribution of powers prescribed by the Constitution Act, 1867, Strayer, J. stated that it remained to be seen whether the same principle should apply where the declaration sought related to possible conflicts with the Charter since, as he went on to note, purported violations of the Charter do not imply an unauthorized intrusion of federal authorities into provincial jurisdiction. ${ }^{57}$

The jurisdiction of a provincial superior court to declare an enactment inoperative on account of a Charter violation was subsequently considered by the Supreme Court of British Columbia in Lavers v. Minister of Finance et al. ${ }^{58}$ In that case a petition was brought before McEachern, C.J. in which sections 11(h) and 24 of the Charter were invoked in a challenge to the validity of penalties assessed under the Income Tax Act. ${ }^{59}$ Counsel for the Minister of Finance and the Attorney General for Canada took the position that section 18 of the Federal Court Act ${ }^{60}$ gave exclusive jurisdiction in this matter to the Trial Division of the Federal Court. ${ }^{61}$ Chief Justice McEachern disagreed and, in concluding that the British Columbia Supreme Court had "at least coordinate jurisdiction in Charter matters with the Trial Division of the Federal Court", ${ }^{62}$ eschewed the distinction between challenges to legislation based on the relative distribution of powers set out in the Constitution Act, 1867 and Charter based challenges. Chief Justice McEachern was upheld in this view by the British Columbia Court of Appeal. In that regard Lambert, J.A., stated as follows: ${ }^{.3}$

I agree with Chief Justice McEachern that the decisions of the Supreme Court of Canada in A.G. Canada v. Law Society of B.C., (1982) 137 D.L.R. (3d) 1, [1982] 2 S.C.R. 307, 66 C.P.R. (2d) 1 (the Jabour Case) and Canada Labour Relations Board v. Paul L'anglais Inc. (1983), 146 D.L.R. (3d) 202, [1983] 1 S.C.R. 147, 83 C.L.L.C. $\S 14,033$, confirmed that the Supreme Court of British Columbia has jurisdiction, as a Provincial court of general original jurisdiction, to declare that a particular application of federal legislation is contrary to the Constitution. I have no doubt that the principle confimed by those decisions applies to declarations respecting applications of the Charter to federal legislation in the same way as to declarations respecting applications of ss. 91 and 92 of the Constiturion Act, 1867 to federal legislation. Nor do I think that those two decisions can be confined to cases of the total unconstitutionality of particular federal legislation as opposed to cases of the unconstitutional application of otherwise constitutional legislation. In both the Jabour case and the L'Anglais case the legislation in

57.

58.

59.

60.

61.

62.

63.

Ibid. at 164-66.

(1985), 18 D.L.R. (4th) 477.

S.C. 1970-71-72, c.63, as am.

Supra, note 47.

Re Lavers v. Minister of Finance, supra, note 58 at 478.

Ibid. at 479.

(1990), 64 D.L.R. (4th) 193 at 200-201. While Lambert, J.A. dissented in respect of the major question for resolution, he nonetheless spoke for the majority of the court in so far as the jurisdiction of a provincial superior court to declare a federal enactment unconstitutional is concerned. In that regard see the comments of Wallace, J.A. at p. 219. 
question was constitutional. It was the particular application in question that was said to be beyond the powers of Parliament. In that respect this case is indistinguishable from those two cases.

The meaning of constitutional validity was directly broached by Marceau J.A. of the Federal Court of Appeal in Attorney General of Canada v. David J. Vincer. ${ }^{64}$ The issue before the court was whether a review committee established pursuant to the Family Allowance Act, $1973^{65}$ had jurisdiction to decide whether a provision of that Act contravened the Charter. In holding that the review committee "was not entitled to challenge the constitutionality of the legislative enactments it was called to interpret and apply"66 Marceau, J.A. noted that it did not matter that "what was involved was the supremacy of the Charter and a possible case of 'inoperativeness ' (having as force and effect) and not the separation of powers and the doctrine of ultra vires: the constitutionality of the enactments was no less the issue". ${ }^{67}$ In so doing he echoed a view expressed by Cavarzan in an analysis of the predecessor provision to the notice requirement now in force in Ontario. That is: ${ }^{68}$

Can there be any meaningful distinction between laws which are "of no force and effect" as contemplated in section 52(1) of the Charter because they are "inconsistent with" the Constitution, and colonial laws which were held to be "absolutely void and inoperative" because they were "repugnant to" the provisions of an Act of the U.K., Parliament? Section 2 of the Colonial Laws Validity Act provides that:

2. Any colonial law which is or shall be repugnant to the provisions of any Act of Parliament extending to the colony to which such may relate, or repugnant to any order or regulation made under the authority of such Act of Parliament, or having in the colony the force and effect of such Act, shall be read subject to such Act, order, or regulation and shall, to the extent of such repugnancy, but not otherwise, be and remain absolutely void and inoperative.

A law held to be of no force and effect is for all practical purposes, if not in strict theory, no longer a law; it does not further ensure its demise to declare it to be absolutely void and inoperative.

It is submitted therefore, that the concept of constitutional validity is sufficiently broad in scope to ensure that governments have an opportunity to be heard whenever their law-making power, relative to that of the courts, is brought into issue through a Charter based challenge.

Pursuant to subsection 25(2) of the Judicature Act the requirement to give notice in a proceeding is also triggered when the constitutional limits of otherwise valid legislation is brought into question. Such an issue arose for example, in Law Society of British

\footnotetext{
64. [1988] 1 F.C.R. 714.

65. S.C. $1973-74$, c.44.

6. Attorney General of Canada v. Vincer, supra note 64 at 727.

67. Ibid. at 723 , footnote 5 .

68. Supra, note 43 at $79-80$.
} 
Columbia v. Jabour ${ }^{69}$ as a result of the Law Society of British Columbia having petitioned the Supreme Court of that province to declare the Combines Investigation $A c t^{70}$ to be inapplicable to its activities. The same question also commonly arises whenever provincial labour relations boards are called upon to decide whether a particular industry is governed by federal or provincial legislation. ${ }^{11}$ Since the notion of constitutional applicability is based on principles governing the division of powers between Parliament and the provincial legislatures it is submitted that the scope of subsection 25(2) has been left unaffected by the Charter.

\section{B. PROCEEDINGS TO WHICH THE NOTICE REQUIREMENT APPLIES}

The word "proceeding" is neither defined in the Judicature $A c t^{72}$ nor in the Interpretation Act. ${ }^{73}$ However, as it is a term capable of including "every species of activity in matters legal, from an interlocutory application in Chambers to an appeal in a court of last resort ${ }^{174}$ regard must be had to its context in order to properly construe its meaning. ${ }^{75}$ In that regard, it is submitted that the deletion from the notice requirement of the reference to an action in 1981 appears not to have affected the intendment of the provision, namely, that it apply in respect of all civil and criminal actions before provincial courts of superior and inferior jurisdiction. To begin with, the use of the word "proceeding" in an enactment such as the Judicature Act, where references to a court are stipulated to be either to the Court of Queen's Bench or the Court of Appeal, ${ }^{76}$ necessarily implies that the term encompasses both civil and criminal actions before those courts. Moreover, the fact that the same term is not qualified by any reference in the notice requirement to a particular forum also suggests that it includes actions before provincial courts of inferior jurisdiction. Finally, as was noted by Lieberman J.A. of the Alberta Court of Appeal in $R$. v. Crate, ${ }^{77}$ though a party challenging the constitutional validity of an enactment may have complied with the notice requirement at trial, on appeal notification will still have to be given of the renewed proceedings. ${ }^{78}$

It is submitted that compliance with the requirements of section 25 of the Judicature Act is also a condition precedent to raising a constitutional question before provincial boards and tribunals. In that regard no constitutional prohibition appears to exist against

(1982), 137 D.L.R. (3d) 1 (S.C.C.) aff'g; (1981), 115 D.L.R. (3d) 549 (B.C.C.A.) rev'g; (1979), 98 D.L.R. (3d) 442 (B.C.S.C.).

R.S.C. 1970 , c.C-23; S.C. $1974-75-76$, C.76; S.C. 1976-77, C.28. Pursuant to S.C. 1986, C.26, s.19 the Combines Investigation Act is now cited as the Competition Act.

E.g. see: Canada Labour Relations Board v. Paul L'Anglais, [1983] 1 S.C.R. 147.

Supra, note 1.

R.S.A, 1980, c.I-7.

Per Anderson, J. (dissenting), Attorney General of Ontario v. Palmer et al (1979), 108 D.L.R. (3d) 349 at 358 (Ont. C.A).

Picard v. Public Service Staff Relations Board, [1978] 2 F.C. 296 at 297 (C.A):

Supra, note 1 at s.1.

(1983), 1 D.L.R. (4th) 149.

Ibid. at 152. 
vesting provincial boards and tribunals with the authority to decide questions of constitutional law in the exercise of their jurisdiction. ${ }^{79}$ As such, when so empowered, a board or tribunal may be called upon to decide whether a particular provision is intra vires the enacting legislature and, if so, whether it is applicable in a particular set of the circumstances. ${ }^{80}$ By the same token a board or tribunal can also constitute a court of competent jurisdiction when empowered to deal with challenges under the Charter. ${ }^{81}$ It would therefore be consistent with the purpose for which the notice requirement was enacted for the notion of a proceeding to be interpreted to include adjudicative processes provided for under statute before boards and tribunals.

A further question which arises is whether the word "proceeding" includes actions before courts established under section 101 of the Constitution Act, 1867. In Nisshin Kisen Kaisha Ltd. v. CNR et al ${ }^{82}$ notice of a challenge to the constitutional validity of section 648 of the Canada Shipping Act ${ }^{83}$ was given by the Appellant to the Attorney General for British Columbia and the Attorney General for Canada pursuant to section 8 of the Constitutional Questions Act ${ }^{84}$ with the result that both Attorneys General applied for leave to intervene and file memoranda with the Federal Court of Appeal. The applications were dismissed, though the reason therefore did not relate to the merits of the applications but rather, stemmed from the court's finding that on the facts of the case, a constitutional issue did not arise. It is likely that if the facts had been otherwise the applications would have been allowed, though, not on the basis of Constitutional Questions Act but, rather, by virtue of Rule 1101 of the Federal Court Rules. ${ }^{85}$ Rule 1101 applies in respect of proceedings before the Federal Court of Appeal and provides that where any constitutional question or any question of general importance is raised any party may serve a notice on the Attorney General of Canada or the Attorney General of any interested province, and the Attorneys General so served may apply for leave to intervene "or for leave to file a memorandum of fact and law and to appear by counsel and take part in the hearing". ${ }^{86}$

R. v. Big M Drug Mart Lid. (1985), 18 D.L.R. (4th) 321 at 367 (S.C.C.) and Cuddy Chicks Lid. v. Ontario Labour Relations Board et al (1990), 62 D.L.R. (4th) 125 at 130-32 (Ont. C.A.). See also Hogg, P.W., Constitutional Law of Canada, 2d ed. (Toronto: Carswell, 1985) at 162-3.

Cuddy Chicks Lid. v. Ontario Labour Relations Board, supra, note 79 at 130 citing Northern Telecom Ltd. v. Communication Workers of Canada, supra note 8; Four B. Manufacturing Lid. v. United Garment Workers of America, [1980] 1 S.C.R. 1031 and Canada Labour Relations Board v. Paul L'Anglais, supra, note 71.

E.g. see: Shewchuk v. Ricard et al (1986), 28 D.L.R. (4th) 429 at 439-40 (B.C.C.A); Re United Nurses of Alberta Local 115 and Foothills Provincial General Hospital Board (1987), 40 D.L.R. (4th) 163 at 167, 168 and 169 (Alta. Q.B.); Zwarich v. Attorney General for Canada (1987), 3 F.C.R. 253 at 255 (F.C.T.D.).

(1981), 121 D.L.R. (3d) 723 (F.C.A.).

R.S.C., 1970, c.S-9.

Supra, note 2.

C.R.C., c.663, as am.

Ibid. 
As no provision similar to Rule 1101 exists in respect of proceedings before the Trial Division of the Federal Court, it is arguable that provincial notice requirements would be applicable to proceedings before the court, if not directly, then as a consequence of Rule 5 of the Federal Court Rules, ${ }^{87}$ also referred to as the Gap Rule. For example, in Brywall Manufacturing Ltd. v. Try-1 International Ltd. et al ${ }^{88}$ the Gap Rule was invoked to permit an intervention by a non-governmental party pursuant to articles 208 to 215 of the Quebec Code of Civil Procedure. ${ }^{89}$ The possibility of applying the Gap Rule in respect of governmental interveners was canvassed by the Trial Division of the Federal Court in Alberta Government Telephones v. Canadian RadioTelevision and Telecommunication and CNCP Telecommunications. ${ }^{90}$ The case arose as a result of a motion by the Attorney General for Canada to intervene in a proceeding instituted by Alberta Government Telephones in which a writ of prohibition was sought to prevent the CRTC from proceeding with an application by CNCP Telecommunications for an order compelling Alberta Government Telephones to afford CNCP Telecommunications access to its telecommunication facilities. The court reviewed its authority to permit the intervention sought and, in particular, considered the applicability of section 25 of the Judicature Act in light of the Brywall ${ }^{1}$ case. However, in granting the application and adding the Attorney General for Canada as a party Respondent to the prohibition proceedings the court declined to decide upon the applicability of the provincial notice requirement, holding instead that the application should be granted on the basis that it was desirable in the circumstances to add the Attomey General as a party in light of Parliament's interest in maintaining control over telecommunications. An appeal from this decision was taken to the Federal Court of Appeal ${ }^{92}$ which, after noting the absence of a rule governing interventions before the Trial Division, held that the lower court had jurisdiction to permit interventions in appropriate circumstances and that it had properly exercised its discretion in this regard in permitting an intervention by the Attorney General

87.

Ibid.

Rule 5 of the Federal Court Rules provides as follows:

5. In any proceeding in the Court where any matter arises not otherwise provided for by any provision in any Act of the Parliament of Canada or by any general rule or order of the Court (except this Rule), the practice and procedure shall be determined by the Court (either on a preliminary motion for directions, or after the event if no such motion has been made) for the particular matter of analogy

(a) to the other provisions of these Rules, or

(b) to the practice and procedure in force for similar proceedings in the courts of that province to which the subject matter of the proceedings most particularly relates, whichever is, in the opinion of the Court, most appropriate in the circumstances.

(1975), 19 C.P.R. (2d) 38.

Supra, note 2.

[1983] 2 F.C. 443.

Supra, note 88.

[1983] 2 F.C. 839. 
for Canada. ${ }^{93}$ The Court declined, however, to make the Attorney General a party respondent ${ }^{94}$ and in so doing appears to have implicitly decided that the provincial notice requirement, which deems the status of the Attorney General to be equivalent to that of a party, ${ }^{95}$ was inapplicable to proceedings before the Trial Division of the Federal Court.

It is submitted that federal boards, commissions and tribunals constituted or established under an Act of Parliament are also beyond the reach of provincial notice requirements. The powers of Parliament and the Provincial legislatures are limited by the Constitution Act, 1867. Whereas Parliament can legislate on the subject matters referred to it by section 91 of the Constitution Act, 1867, a Provincial Legislature can legislate only on the subject matters referred to it by section $92 .{ }^{96}$ Hence, where the jurisdiction of federally constituted boards, commissions and tribunals to administer federal legislation derives exclusively from a grant of power under an Act of Parliament, Provincial legislation which purports to affect procedure before such boards, commissions and tribunals would be ultra vires the enacting legislature. ${ }^{97}$ The situation may be otherwise, however, in respect of proceedings before provincial boards exercising authority granted under a federal statute. As previously noted, provincial rules of procedure may still be applicable if Parliament does not enact its own code of procedure for the exercise of delegated federal powers. ${ }^{98}$

\section{STATUTORY INSTRUMENTS ENCOMPASSED BY REFERENCE TO AN ENACTMENT}

It is clear from the terms of section 25 of the Judicature Act that the requirement to give notice only arises in respect of challenges to the constitutional validity of federal and provincial enactments. In other words, one is not required to notify the Attorneys General for Canada and Alberta of applications under section 24 of the Charter for the enforcement of guaranteed rights or the exclusion of evidence on the grounds that it brings the administration of justice into disrepute. What remains to be determined, therefore, are the statutory instruments encompassed by references to an enactment of Parliament and an enactment of the Legislature of Alberta. As neither of these terms are defined in the Judicature Act one is obliged to turn to the provincial Interpretation Act ${ }^{99}$ for assistance. Paragraphs 25(1)(a) and 25(1)(e) of that Act provide that references to an enactment include Acts of the Legislature of Alberta, Ordinances of the North West

\footnotetext{
93. Ibid. at $839-40$.

9. Ibid. at 840 .

95. Judicature Act, supra, note 1 at subsection 25(5).

96. Attorney General of Nova Scotia v. Attorney General of Canada (Interdelegation Case), [1951] S.C.R. 31.

9. For a discussion of the constitutional aspects of Canadian Administrative Law see Jones, D.P. and deVillars, A.S. Principles of Administrative Law (Toronto: Carswell, 1985) at 23-25.

9. Re B.C. Tree Fruit Marketing Board and R.H. MacDonald and Sons, supra, note 42.

9. Supra, note 73.
} 
Territories in force in Alberta and regulations, as well as any portion of these instruments. A regulation is further defined in paragraph 1(1)(c) of the Interpretation Act to include,

a regulation, order, rule, form, tariff of costs or fees, proclamation, by-law or resolution enacted,

(i) in the execution of a power conferred by or under the authority of an Act, or

(ii) by or under the authority of the Lieutenant Govemor in Council.

The provincial Interpretation Act is silent as to what constitutes an enactment of Parliament. Since words must be construed in the light of facts known to the Legislature of Alberta at the time the notice requirement was enacted ${ }^{100}$ it is submitted that its intention can be ascertained by referring to the definition of an enactment of Parliament found in the federal Interpretation Act. ${ }^{101}$ This definition encompasses a similar range of statutory instruments as does the reference to an enactment of the Legislature of Alberta. That is, in addition to Acts and regulations an enactment of the Parliament of Canada is defined to include, ${ }^{102}$

an order, regulation, rule, rule of court, form, tariff of costs or fees, letters patent, commission, warrant, proclamation, by-law, resolution or other instrument issued, made or established,

(a) in the execution of a power conferred by or under the authority of an Act or

(b) by or under the authority of the Governor in Council.

\section{OBJECTIONS TO THE NOTICE REQUIREMENT}

Two objections have been raised to provincial notice requirements: ${ }^{103}$

(1) Pursuant to section 52 of the Constitution Act, 1982 the Constitution of Canada is the supreme law of Canada and, as such, one ought to be able to invoke it without having to give special notice.

Driedger, E.A., Construction of Statutes, 2d ed. (Toronto: Butterworths, 1983) at 149 citing A.G. v. Ernest Augustus (Prince) of Hanover, [1957] A.C. 436 at 465 (H.L.). In that regard Lord Normand stated as follows:

In order to discover the intention of Parliament it is proper that the court should read the whole Act, inform itself of the legal context of the Act, including Acts as related to it that they may throw light upon its meaning, and of the factual context, such as the mischief to be remedied and those

10. R.S.C., 1985, c.I-21. circumstances which Parliament had in view.

102. Ibid. at s. 2.

103. Supra, note 29. 
It is contrary to section 15 of the Charter to permit a provision such as section 25 of the Judicature Act to remain in force given the possibility that access to Charter rights might vary from province to province through the enactment of different notice requirements.

Insofar as the applicability of section 52 of the Constitution Act, 1982 is concerned and the question of whether a notice requirement can act as a bar to adjudication by a court on the constitutional validity of a statute, the Alberta Court of Appeal in the Stanger case $^{104}$ found section 25 of the Judicature Act to be only a procedural provision. That is, by not precluding one from ultimately securing relief under the Charter, the notice requirement did not affect substantive rights and therefore, was constitutionally unobjectionable. However, the same court in Broddy and Broddy v. Director of Vital Statistics ${ }^{105}$ denied access to Charter rights to Appellants who, in arguing for dismissal of a refusal by a lower court to issue a writ of mandamus requiring the Respondent to issue a marriage license, invoked section 7 of the Charter without giving notice in accordance with section 25 of the Judicature Act. In explaining the Court's refusal to hear the Appellant's Charter arguments Kerans, J.A. stated as follows: ${ }^{106}$

...this issue is not properly before us. There is nothing to indicate that written notice in this regard...had been given to the Attomey General for Canada or to the Attomey General for Alberta. In my view, a proposal to read down in light of the Charter is also an attack on validity and s. 25(4) (re-en. 1981, c.51, s.2(a) of the Judicature Act, R.S.A. 1980 c.J-1) applies. The practice of this court is to require strict adherence to these provisions. Accordingly, I will not deal with the Charter issue.

However, as Stevenson, J.A. noted in the Stanger case, different considerations would have applied if the party seeking a declaration of invalidity had sought an adjournment to permit notice to be given. ${ }^{107}$

Strict compliance with the terms of section 25 of the Judicature Act was recently required by Berger, J. of the Court of Queen's Bench of Alberta in Bourque et al v. The Chief Electoral Officer and Her Majesty the Queen in Right of Canada. ${ }^{108}$ On November 5, 1988 residents of an urban polling division in Edmonton learned that they had been left off the official list of electors and would not be permitted to vote in the federal general election of November 21, 1988 since, unlike qualified electors residing in rural polling divisions, they were ineligible for inclusion in the official list of electors under any of the exceptions set out in paragraphs 39(2)(a) and 39(2)(b) of the Elections Act. ${ }^{109}$ By Originating Notice filed on November 14, 1988 the disqualified electors brought a motion for, firstly, an order pursuant to subsection 24(1) of the Charter

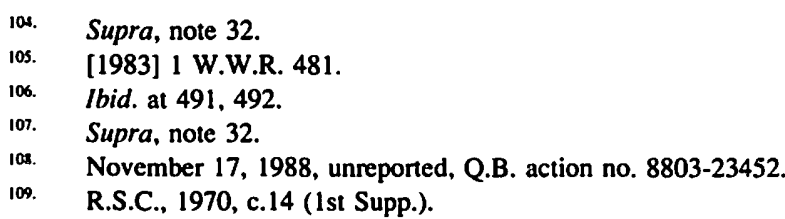


permitting them to vote and, secondly, a declaration pursuant to section 52 of the Charter that subsection 39(1) of the Elections Act is of no force and effect to the extent that it deprives qualified electors in urban polling divisions of the right to vote. ${ }^{110}$ In particular, the Applicants submitted that: ${ }^{111}$

(1) The prohibition against voting constitutes a denial of their right to vote enshrined by section 3 of the Charter, and is also an infringement of their liberty protected by section 7 of the Charter.

The difference in treatment between electors in urban polling divisions and electors in rural polling divisions is discriminatory and infringes their right to equal benefit of the law pursuant to section 15 of the Charter.

However, Berger, J. declined to deal with the merits of the application dismissing it instead on the grounds that notice had not been properly provided in accordance with section 25 of the Judicature Act. ${ }^{12}$

It is submitted that the prohibition against finding an enactment to be constitutionally invalid where the notice requirement has not been complied with does not mean that in the event of non-compliance, a court is left with no option but to refuse to deal with the constitutional question. For example it can equally comply with the prohibition by adjourning proceedings and allowing the party bringing the challenge time to give the requisite notice. Such might be appropriate where a delay in proceedings does not cause the opposing party undue prejudice and where the conduct of the action by the party bringing the challenge does not otherwise militate against the granting of an adjournment. It may even be possible to proceed with the hearing of the constitutional question without having to adjourn if the Attorneys General for both levels of government waive their right to notice under section 25 of the Judicature Act. If one of the purposes of the notice requirement derives from the need to ensure that governments are represented in actions where the constitutional validity of their legislation is in issue, then so long as the federal and provincial Attorneys General feel they would not be prejudiced by a decision in which the views of their government were not expressed, it should be open to the court to accept such waiver and proceed with the hearing. ${ }^{113}$

In certain circumstances it may be appropriate for a court to waive compliance with the notice requirement even if such is not consented to by the Attorneys General for the federal and provincial governments. In Re Children's Aid Society ${ }^{114}$ the Children's Aid Society of Winnipeg applied to the Manitoba Court of Queen's Bench to obtain permanent

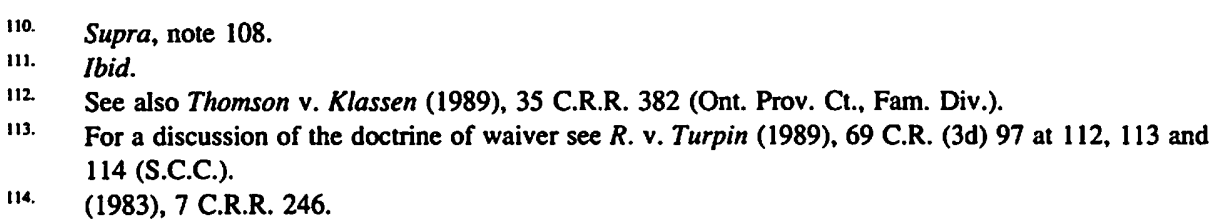


wardship of a child. The application was made without the presence of the child or the parents, though notice of the application had been given to the parents. Following the granting of the permanent wardship order to the Children's Aid Society, counsel acting on behalf of the child's aunt appealed to the Manitoba Court of Appeal. In so doing, an application was made to Matas, J.A., sitting in Chambers, to have the child added as a party and as well, to have counsel appointed for the child. With regards to the latter application, counsel for the Appellant argued that the question of child representation in the courts is governed by section 7 of the Charter. That is: ${ }^{115}$

...the principles of fundamental justice are at least equivalent to the principles of natural justice, audi alteram partem applies and all children regardless of age, are entitled to be present at a hearing and to be represented by counsel.

In response, counsel for the Children's Aid Society noted that, by raising as an issue the applicability of section 7 of the Charter, the Appellant was inferentially impugning the validity of subsection $25(7)$ of the Child Welfare Act ${ }^{16}$ which provides that it is for the presiding judge to decide whether counsel should be appointed for unrepresented children in permanent wardship applications. It was argued that, in raising the constitutional question counsel for the Appellant should have notified the federal and provincial Attomeys General in accordance with the requirement set forth in section 73 of the Queen's Bench Act. ${ }^{177}$ Matas, J.A. held, however, that the failure to give such notice did not bar him from dealing with the merits of the Appellant's argument respecting the applicability of section 7 of the Charter to the question of a child's right to counsel. In that regard he stated as follows: ${ }^{18}$

Differing opinions have been expressed about whether notice is required in every case where legislation is arguably affected by the Charter. Our practice in this court is to have notice given to the federal and provincial Attomeys General. In my view, this is a desirable practice, but it is not a rule of law. It is my opinion that because section 52 of the Constitution Act, 1982 declares that the constitution is the supreme law of Canada, it is not necessary to give notice in every case. Here, time constraints do not permit it. The motion can be heard in the absence of notice.

It is arguable, therefore, that section 25 of the Judicature Act should similarly be read down when the effect of enforcing compliance with its terms would be to bar an individual from seeking relief under the Charter. Such an interpretation might have been appropriate, for example, in the Bourque case ${ }^{119}$ if the date on which the Applicants had brought their motion namely, 7 days prior to the federal general election had also been the date on which they first became aware of their disenfranchisement.

\footnotetext{
115. Ibid. at 254.

116. 1974 (Man.), c.30 (C.C.S.M. c. C80).

117. R.S.M. 1970, c.280, (C.C.S.M., c. C280).

118. Re Children's Aid Society, supra, note 114 at 254.

119. Supra, note 108.
} 
Of course, any analysis relating to the necessity of complying with section 25 of the Judicature Act must still be viewed in the context of principles which otherwise govern the conduct of litigation. In that regard, compliance with the notice requirement constitutes at best, a necessary condition to challenging the constitutional validity of enactments. It does not by itself secure one's entitlement to do so. For example, even where there has been compliance with the notice requirement, an appellate court may still decline to hear a challenge to the constitutional validity of an enactment if it is raised for the first time on appeal without the relevant evidence having been led at trial. While it is within the power of an appellate court to admit such evidence, it may refuse to do so if the facts sought to be established are in dispute. As Kerans, J.A. of the Alberta Court of Appeal noted in $R$. v. Moisan, ${ }^{120}$ an appellate court is not structured to hear and decide disputed questions of fact and as such, parties are generally expected to lead all their evidence at trial.

The other objection to provincial notice requirements namely, that they do not comply with subsection 15(1) of the Charter, arises from the possibility of provincial legislatures enacting different forms of notice requirements, be it in respect of the content, timing or circumstances in which notice is to be given. For example, whereas one Province may require 14 days written notice before a court is permitted to adjudicate upon a challenge to the constitutional validity of an enactment, another Province may permit the same challenge to be brought without having to give any notice. It is submitted, however, that such differences do not violate an individual's right to the equal protection and equal benefit of the law. That is, the fact that provinces and territories may pass different laws in relation to the same subject matter does not give rise to an infringement of subsection 15(1) of the Charter. ${ }^{121}$ In Feener v. The Queen ${ }^{122}$ an appeal was taken from the decision of Hallett, J. of the Trial Division of the Nova Scotia Supreme Court dismissing an application to have provincial mandatory seat belt legislation declared invalid on the grounds that it contravened sections 7 and 15 of the Charter. The Appellant contended that "s. 7 permitted anyone to do with his body as he pleased and that section 15 prevented anybody from being convicted of an offence that could not apply to all other Canadians as well. ${ }^{123}$ In dismissing the appeal Hart, J.A., on behalf of the Appellate Division of the Nova Scotia Supreme Court, stated as follows: ${ }^{124}$

In my opinion, the trial judge properly rejected these arguments as there was no evidentiary basis established under section 7 and since section 15 did not prevent a province from passing laws within its legislative competence that could affect only the residents of this province.

\footnotetext{
120. (1987), 56 C.R. (3d) 188 at 192.

121. Indeed, in R. v. Turpin, supra, note 113, the Supreme Court of Canada has gone so far as to hold that it is not a fundamental principle under section 15 of the Charter that even a federal law such as the criminal code apply equally throughout the country.

122 (1987), 78 N.S.R. (2d) 22 (N.S.C.A.).

123. Ibid. at 23 .

124. Ibid.
} 
Leave to appeal to the Supreme Court of Canada was denied. ${ }^{125}$

\section{INTERVENTIONS AND THE GOVERNMENTAL INTEREST}

A finding that the notice requirement is constitutionally valid begs the question of why the Attorney General for one level of government would be interested in litigation that brings into issue the vires of the other government's legislation. Of course, where the challenge is based on the interpretation of sections 91 and 92 of the Constitution Act, 1867 the interest of both governments is necessarily engaged since the outcome of the challenge will affect the relative distribution of powers between them. However, when the challenge is based on the Charter the only matter in issue is the jurisdictional scope of the enacting body to abridge or regulate individual activity. Since it does not raise an issue as to the relative balance of responsibility between the two levels of government the question which needs to be asked is how the courts' role as arbiters of the federal system is enhanced by the participation of both Attorneys General.

It is submitted that the Attorneys General for Canada and the provinces have an interest in intervening in litigation which seeks to impugn the constitutional validity of legislative schemes which are either similar to their own or within their competence to enact. For example, by virtue of their governments' responsibilities in respect of the incorporation of companies pursuant to subsection 92(11) of the Constitution Act, 1867, Provincial Attomeys General are obliged to take heed of decisions which deal with the constitutionality of provisions under the Canada Business Corporations Act. ${ }^{126}$ It is further submitted that the case for granting the Attorneys General for Canada and the provinces the power to intervene in constitutional litigation, where the validity of their governments' legislation is not in issue, also derives from the interdependence of Parliament and provincial legislatures and the consequent need for co-operative action. As was explained by Hogg: ${ }^{27}$

The formal structure of the Constitution carries a suggestion of eleven legislative bodies each confined to its own jurisdiction and each acting independently of the others. In fact each of the "coordinate and independent" bodies finds that many of the policies it would approve have repercussions outside its jurisdiction, and the effective pursuit of these policies requires the joint, or at least complimentary, action of more than one legislative body.

For example, while jurisdiction over criminal law resides in Parliament, responsibility for its enforcement by police and prosecutors is generally exercised pursuant to provincial power over the administration of justice. ${ }^{128}$ In an effort to deal with problems on a

125. (1987), 79 N.S.R. (2d) 270.

126. 1974-76, S.C., c.33.

127. Hogg, Constitutional Law of Canada, supra, note 79 at 106.

128. See De Iorio and Fontaine v. Warden of Cammon Jail of Montreal and Brunet et al. (1976), 35 C.R.N.S. 57 (S.C.C.). However, the Supreme Court of Canada subsequently held in R. v. Hauser et al.; (1979), 8 C.R. (3d) 89, the Supreme Court of Canada held that Parliament has concurrent 
regional basis Parliament sometimes passes laws which are not uniformly applicable in Canada. For example, the Combines Investigation Act ${ }^{129}$ prohibits pyramid selling schemes unless they are operated in provinces which have regulatory or licensing statutes governing pyramid selling. Co-operation is also fostered by the availability of legislative techniques such as referential incorporation which permits one legislative body to incorporate by reference the rules of another jurisdiction. For example, rather than enact its own procedural code for prosecutions of provincial offenses under the Provincial Offences Procedure Act, ${ }^{130}$ the Legislature of Alberta incorporated by reference most of the provisions under Part XXVII of the Criminal Code. ${ }^{131}$ Co-operative federalism is therefore central to the effective governance of Canada. As a consequence, the manner in which its evolution is shaped through constitutional litigation is of interest to the federal and provincial governments, no matter whose legislation is being impugned.

\section{CONCLUSION}

The role carved out by the notice requirement for the Attorneys General for Canada and Alberta in constitutional litigation is a broad one, arising in respect of challenges to the constitutional validity and applicability of federal and provincial enactments which are brought before courts of superior and inferior jurisdictions as well as provincial boards and tribunals. Authorized by subsection 92(14) of the Constitution Act, 1867 the notice requirement is neither rendered constitutionally objectionable by section 52 of the Constitution Act, 1982 nor by the possibility of different notice requirements being enacted by other provincial legislatures. It is submitted, however, that the nature of Charter litigation requires a purposive rather than strict interpretation of the terms of section $\mathbf{2 5}$ of the Judicature Act. Indeed, the wording of the notice requirement invites such an approach since, apart from precluding a court from holding an enactment to be either constitutionally invalid or inapplicable in the absence of the requisite notice, no other direction is given as to how a court is to deal with instances of non-compliance. It is submitted therefore, that in order not to preclude parties from ultimately securing relief under the Constitution Act, 1982, compliance with the notice requirement should be dispensed with where, compliance is not possible but notice of the constitutional challenge was given as soon as circumstances permitted.

authority with the provinces over the enforcement of Criminal Law.

129. Supra, note 70. The validity of these provisions was upheld by the Manitoba Court of Appeal in The Queen v. C.L.P. Market Lifestyle et al. (1988), 50 M.R. (2d) 106. In arriving at this conclusion the court declined however, to follow a contrary conclusion reached by the Ontario Court of Appeal in R. v. Hamilton (1986), 57 O.R. (2nd) 412 regarding the equal application of subsections $234(2)$ and 236(2) of the Criminal Code (now subsection 239(5)) which provide that a court may grant an accused found guilty of impaired driving or having a blood alcohol concentration of above 80 milligrams in one hundred millilitres of blood, a discharge upon condition that he obtain curative treatment. The equal application of the Criminal Code has since been dealt with by the Supreme Court of Canada in $R$. v. Turpin, supra, note 113.

130. R.S.A., 1980, c. P-21.5.

131. Ibid. s. 3. 
While the role played by the Attorneys General for Canada and Alberta is important it is not one which, in these circumstances, deserves to be protected at the expense of the rights of private litigants. 